\title{
The Effect of Clay Shale Drying on the Reduction of Compressive Strength and Durability in Bawen Sub-District, Semarang Regency
}

\author{
Bambang Pardoyo*, Wikan Sadono Kresno, Dhimas Andra Fahreza, Tubagus Awan Maulana \\ Department of Civil Engineering, Faculty of Engineering, Universitas Diponegoro, Indonesia
}

Received October 5, 2020; Revised December 3, 2020; Accepted December 13, 2020

\section{Cite This Paper in the following Citation Styles}

(a): [1] Bambang Pardoyo, Wikan Sadono Kresno, Dhimas Andra Fahreza, Tubagus Awan Maulana, "The Effect of Clay Shale Drying on the Reduction of Compressive Strength and Durability in Bawen Sub-District, Semarang Regency, "Civil Engineering and Architecture, Vol. 8, No. 6, pp. 1359 - 1369, 2020. DOI: 10.13189/cea.2020.080619.

(b): Bambang Pardoyo, Wikan Sadono Kresno, Dhimas Andra Fahreza, Tubagus Awan Maulana (2020). The Effect of Clay Shale Drying on the Reduction of Compressive Strength and Durability in Bawen Sub-District, Semarang Regency. Civil Engineering and Architecture, 8(6), 1359 - 1369. DOI: 10.13189/cea.2020.080619.

Copyright $\bigcirc 2020$ by authors, all rights reserved. Authors agree that this article remains permanently open access under the terms of the Creative Commons Attribution License 4.0 International License

\begin{abstract}
Clay shale has unstable properties even though it is on a slope having a gentle slope. This raises many geotechnical problems. This study aims to determine the effect of clay shale drying on compressive strength and durability reduction by using samples taken from Kandangan Village, Polisiri Village, Bawen Sub District, Semarang Regency and Central Java. The drying process simulates when the open cut excavation process is exposed to sunlight, such as road excavations and bored pile excavations. The method used is testing the physical property, property of rocks and mechanical property with drying at intervals of 0 minute, 30 minutes, 60 minutes, and 90 minutes. Initial condition of sample had 23 percent - 31 percent of vulnerable water content. The influence of drying can reduce the value of water content; clay shale is really easy in creating the weathering; and all samples of shale clay have very low durability properties. Of all the UCS test samples, it can be said that the longer the drying, the greater the percentage of qu value loss. For testing Modulus Elasticity can be said that the longer the drying, the greater the percentage of loss of E50 value and Etan value. The relationship between UCS and Modulus Elasticity (E50 and Etan) values with the duration of the drying is the longer the drying the greater the lost value of UCS and Modulus Elasticity.
\end{abstract}

Keywords Clay Shale, UCS, Slake Durability, Modulus of Elasticity (E50 and Etan)

\section{Introduction}

Clay shale is formed by clay minerals and clay stones. Terzaghi [1]; Franklin [2]; Bates [3] said that clay shale is a transition material between soil and rock, which causes clay shale easily has reduction in durability which then causes problems in the geotechnical field (Budijanto Widjaja, 2004 ; Gamil, Zamahri, \& Bakar, 2018).

This Clay shale is easily fragmented in the form of fragments if it has direct contact with the air outside, and the result is it has reduction in water content. On the construction stage of open excavation, for instance, the cuts on the slope of clay shale that is exposed sunlight directly, it can be reduce the stability of slope.

One of examples of an avalanche occurring on clay shale is on the Highway in Semarang 32+000 Bawen kilometers, Central of Java. The case happens since it caused by open cut on open Highway construction by the outside air and has a reaction with the atmosphere. The Highway of Semarang 32+000 Bawen kilometers lies on hoist formation. [25].

The study about the drying has been conducted by Ariesnawan (2015), analyze about the effect of water content change toward the characteristics of physical, mechanical and dynamical clay shale with the process of wetting and drying. The sample location is taken from the area of mining in Tuban District. The research founding is the reduction of clay shale power is caused by the fracture caused by flower shrinkage and parameter transition from 
the category of rock to soil due to the effect of weathering. Alatas et al. (2015) conduct the test with the sample which is exposed by sunlight and observing that there is a reduction on cohesion (peak stress), internal angel of friction (peak Stress), residual friction with and without stress release, residual cohesion with and without stress release. Ghafoori (1994) analyzes the effect of water content and the degree of weathering on the main property, for instance, uniaxial compressive strength, point load strength index dan unit weight. Gökceoglu, Ulusay, and Sönmez (2000) measure the effect of the number of drying cycle and the discussion on the effect of mineral toward the strength and durability on the sample in Turkey. Some of researchers try to correlate the slake durability index (SDI) with the characteristic of other geologies (Marques, Vargas, and Antunes 2005). Alatas and Simatupang (2017) study about the change of physical characteristic of clay shale because of the effect of weathering is determined by the ratio disintegrated (DR) in Semarang- Bawen. Ration Disintegrated is a ratio of physical change which is the effect of weathering on certain time toward its initial condition. Regarding of the correlation proposed, SDI not only depends on one material property. The previous research only reviews the durability and clay shale weathering, but it has never reviewed the strength of clay shale and elasticity modulus on the condition exposing the sunlight.

This research aims to know the duration of clay shale strength expose by the sunlight will last during the construction execution. The strength and durability of clay shale is a free press test and elasticity modulus. The construction execution needs to maintain the clay shale condition in order to be not exposed by the sunlight, for instance cliff cutting on the street construction and excavation on dam construction that should be closed again, and bore pile holes that should be filled with concrete and reinforcement.

This research is reviewed the drying clay shale in constant temperature to know the strength of clay shale. The strength meant is free press test. After clay shale has the process of drying in constant interval time, the reduction of clay shale strength is able to be discovered. The research location is hoist formation which is also the same formation crossed by highway, Semarang-Bawen $32+000$ kilometers.

\section{Location}

Based on the information from the Prone Map of the Central Java Land Movement released by Department of Energy and Mineral Resources [13], based on geological maps, Kandangan and Police village include in Kerek formation i.e., clay stone and both of them also include in vulnerability zone.

Based on 2 (two) considerations above, the sampling locations in this study taken from the Village of Kandangan and the Village of Police, Bawen Sub District, Semarang Regency, Central Java with the coordinates that presented in Table 1 and the map in Figure 1 (Google Earth).

Table 1. Location Coordinates for Sampling

\begin{tabular}{|c|c|c|}
\hline \multirow{2}{*}{ Sample } & \multicolumn{2}{|c|}{ Coordinate } \\
\cline { 2 - 3 } & $\mathrm{S}$ & $\mathrm{E}$ \\
\hline L 1 & $7^{\circ} 13^{\prime} 41.62^{\prime \prime} \mathrm{S}$ & $110^{\circ} 29^{\prime} 4.65^{\prime \prime} \mathrm{E}$ \\
\hline L 2 & $7^{\circ} 13^{\prime} 51.66^{\prime \prime} \mathrm{S}$ & $110^{\circ} 29^{\prime} 6.35^{\prime \prime} \mathrm{E}$ \\
\hline L 3 & $7^{\circ} 14^{\prime} 4.46^{\prime \prime} \mathrm{S}$ & $110^{\circ} 29^{\prime} 12.09^{\prime \prime} \mathrm{E}$ \\
\hline L 4 & $7^{\circ} 13^{\prime} 9.92^{\prime \prime} \mathrm{S}$ & $110^{\circ} 29^{\prime} 19.02^{\prime \prime} \mathrm{E}$ \\
\hline L 5 & $7^{\circ} 13^{\prime} 9.92^{\prime \prime} \mathrm{S}$ & $110^{\circ} 29^{\prime} 20.97^{\prime \prime} \mathrm{E}$ \\
\hline
\end{tabular}

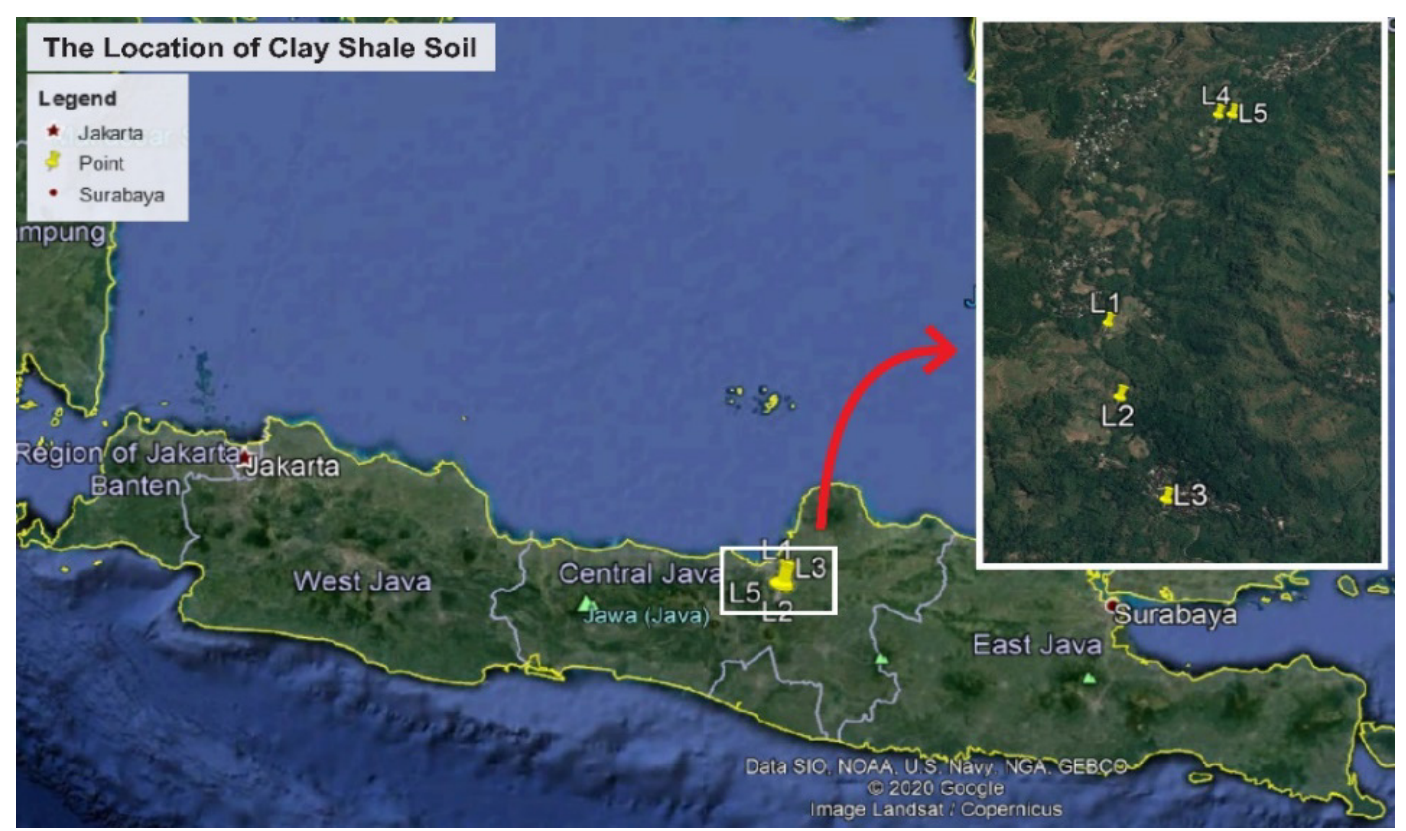

Figure 1. The Location for Sampling in Bawen, Semarang 


\section{Research Methods}

Sampling in the field was done manually by using crowbar. Samples were taken from 5 (five) locations. Taking samples at 5 (five) locations at a depth of $\pm 0.5 \mathrm{~m}$, samples were taken in the form of chunks, so that for each location can produce 5 (five) core samples with a diameter of $50 \mathrm{~mm}$ and a height of $100 \mathrm{~mm}$. Before the sample was taken, the sample was in water so therefore after the sample was taken, the sample was put in a box filled with water to maintain its moisture. This way was done because when taking in the field, generally the sample is submerged by the water. The sample was kept immersed in water until the test was conducted.

Samples taken were then used for testing Wet Density [15], Water Content [16], Specific Gravity [17], Atterberg Limit [18], Free Swell [19], Slake Durability [20], Unconfined Compression Strength (UCS) [21].

In this case, testing of Natural Water Content, Specific Gravity, Wet Density, Liquid Limit, Plastic Limit, and Slake Durability was conducted on 5 (five) samples. The Liquid Limit test was conducted on 5 (five) samples as well, but in this test, it was conducted under Not Over dried and Over dried conditions. Liquid limit testing in Over dried conditions was conducted to evaluate whether the sample contains organic material or not.

UCS testing was conducted to determine the strength of the intact sample at the 5 (five) locations and from each location, there were 4 (four) cylindrical samples with a diameter of $50 \mathrm{~mm}$ and a height of $100 \mathrm{~mm}$, so that the total of 20 (twenty) samples was obtained. The cylinder was formed from chunks of clay shale chunks from the field where the coring was done in the laboratory. After the coring process, the 20 (twenty) samples were put back into the water to maintain their moisture. In the UCS test, unconfined compression strength, axial strain, and water content values were obtained. Each UCS sample at each location has a different drying time interval, starting from 0 minutes, 30 minutes, 60 minutes, and 90 minutes. The drying of samples for UCS is done in a glass box in which 2 lamps were installed as heaters which function to simulate the temperature of sun drying. The temperature in the glass case was set according to the ambient temperature. This was done because the drying process was in direct sunlight. In this case many uncontrolled factors affect the sample, such as wind, dust, unstable temperature, and other risks that can damage the sample.

In determining the drying temperature, an ambient temperature was needed which was calculated by approaching the height and average daily temperature so that the lower bound temperature for the thermostat setting was $29.2{ }^{\circ} \mathrm{C}$. Meanwhile for the upper limit temperature obtained from the ambient temperature obtained directly from the thermostat sensor at $37.1^{\circ} \mathrm{C}$ as can be seen in Figure 2.

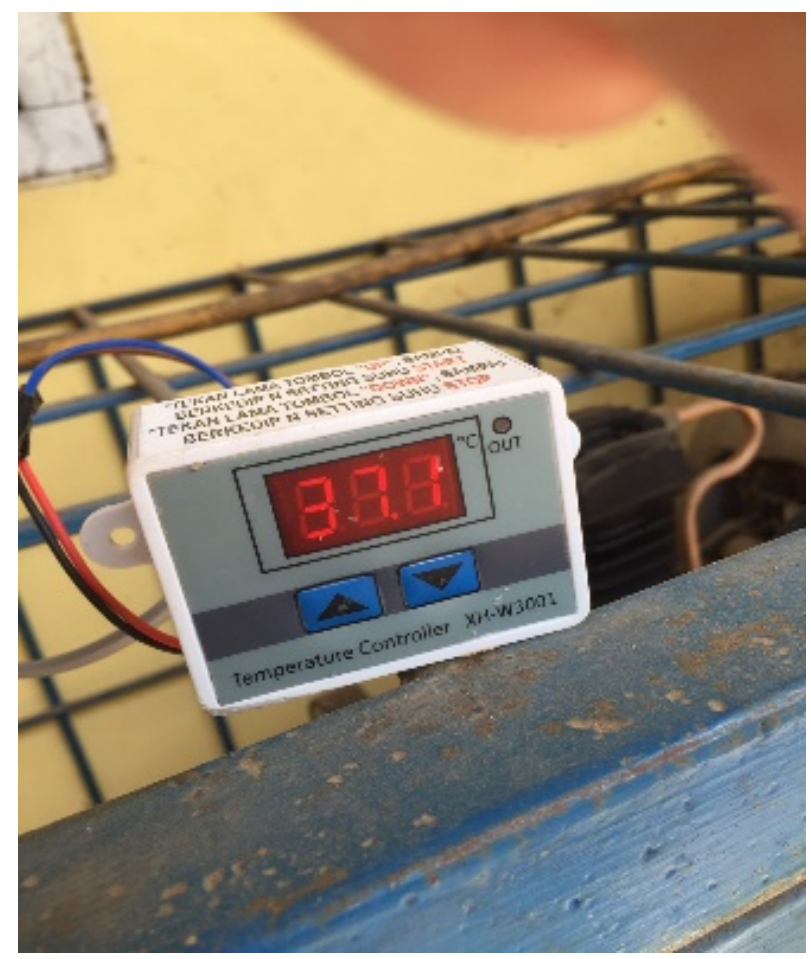

Figure 2. Outside Air Temperature based on Thermostat (upload)

The research method was conducted by testing the Soil Test on the sample to get the moisture content, specific gravity and weight of the wet content. After that, the sample was processed by the Atterberg Limit Test to determine whether the sample is included in clay or silt. Then the Free Swell test was performed to determine whether the sample has high or low swelling. After knowing the soil type, Slake Durability Test was conducted to determine the durability index of the clay shale sample in the first cycle and the second cycle. Meanwhile, to determine the strength reduction of clay shale samples, Unconfined Compression Test was performed on samples obtained from 5 (five) locations, each location has 4 (four) samples with different drying times, namely 0 minutes, 30 minutes, 60 minutes , and 90 minutes. In the Unconfined Compression Test, modulus of elasticity calculation was also performed with a variety of drying time. The test prosedures conducted are: 1) providing 3 samples of clay shale from the same location which have been cylindrical with the diameter: $52 \mathrm{~mm}$ and height: $104 \mathrm{~mm}, 2$ ) wiping the sample on the surface of sample to clean water and dirt marks, 3 ) the sample was scaled to know the initial weight, 4) putting the sample simultaneously in glass box with its temperature reached $31^{\circ} \mathrm{C}$ and below $37^{\circ} \mathrm{C}$ and give the mark on each sample, 5) waiting and observing the crack occurring in samples, 6) taking the sample in one by one when it has reached interval time determined, 7) scaling the sample to know the lost water content, 8) conducting free press test and redo the procedure in 6,7 and 8 stage on the next sample. 


\section{Results and Discussion}

Each sample in this study was tested for natural water content, specific gravity, wet density, liquid limit, and plastic limit. For liquid limits, tests are conducted with over dried and not over dried to look for organic levels, based on the criteria $\frac{\text { LLNot Overdried }}{\text { LL Overdried }}<0.75$ declared organic. The test results for each sample are presented in
Table 2

LL values have a tendency to reduce after going through the over dried process, however the ratio $\frac{\text { LLNot Overdried }}{\text { LL Overdried }}>0.75$ is in the 5 (five) samples. If LL and PI values are plotted into the Plasticity Chart according to Das and Sobhan [22], it can be noticed in Figure 3.

Table 2. Soil Test and Atterberg Limit Test Results

\begin{tabular}{|c|c|c|c|c|c|c|c|c|c|}
\hline \multirow{3}{*}{ Sample } & \multicolumn{3}{|c|}{ Soil Test } & \multicolumn{2}{|c|}{ LL } & \multirow{2}{*}{ PL } & \multirow{2}{*}{ PI } & \multirow{2}{*}{$\begin{array}{l}\text { LL Overdried/LL } \\
\text { Not Overdried }\end{array}$} & \multirow{3}{*}{ Remark } \\
\hline & $\mathrm{w}$ & Gs & $\gamma_{\mathrm{b}}$ & $\begin{array}{c}\text { Not } \\
\text { Overdried }\end{array}$ & Overdried & & & & \\
\hline & $(\%)$ & - & $\left(\mathrm{gr} / \mathrm{cm}^{3}\right)$ & $(\%)$ & $(\%)$ & $(\%)$ & $(\%)$ & $(\%)$ & \\
\hline L 1 & 23.48 & 2.41 & 2.06 & 54.46 & 50.62 & 32.50 & 21.96 & 0.930 & Not Organic \\
\hline $\mathrm{L} 2$ & 27.10 & 2.44 & 1.93 & 84.20 & 65.65 & 43.52 & 40.68 & 0.780 & Not Organic \\
\hline L 3 & 25.04 & 2.36 & 1.96 & 79.09 & 63.68 & 36.71 & 42.38 & 0.805 & Not Organic \\
\hline $\mathrm{L} 4$ & 30.94 & 2.37 & 1.86 & 64.25 & 63.09 & 43.30 & 20.95 & 0.982 & Not Organic \\
\hline L 5 & 30.43 & 2.43 & 1.93 & 66.59 & 56.84 & 40.10 & 26.49 & 0.854 & Not Organic \\
\hline
\end{tabular}

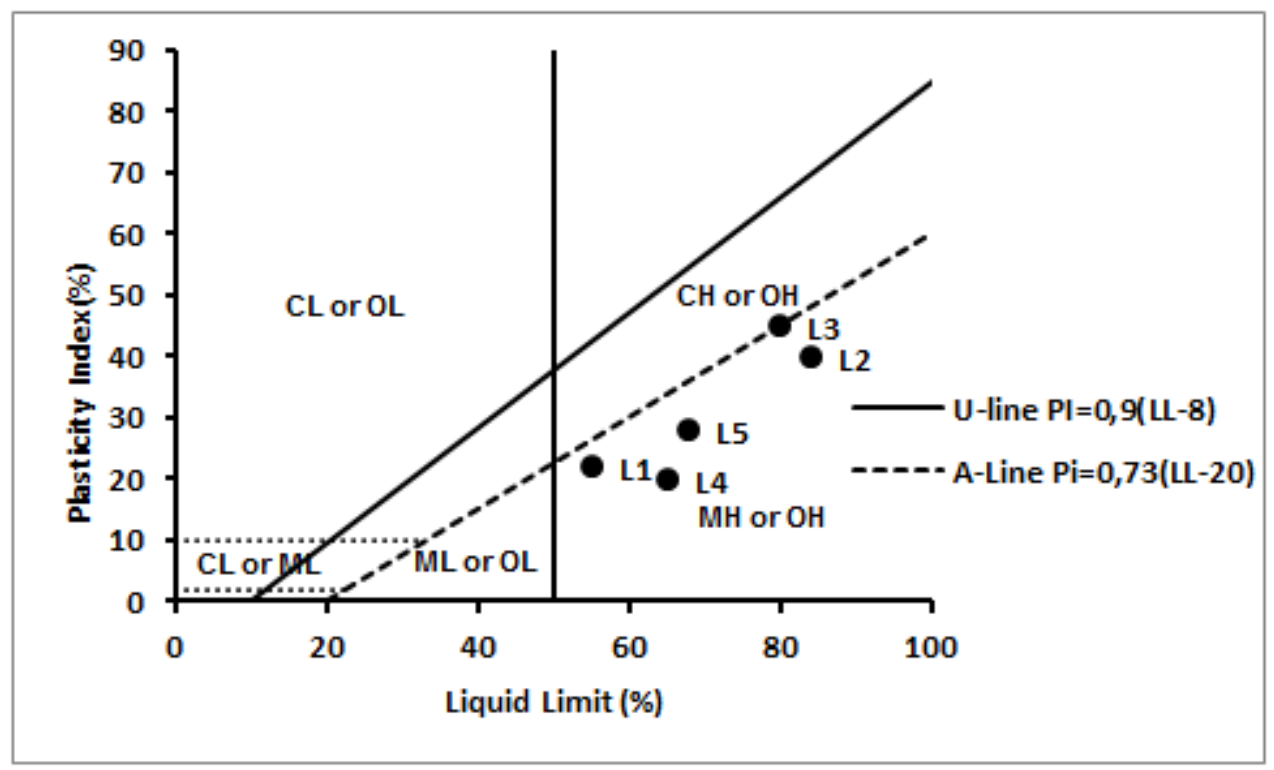

Figure 3. Graph of Sample Plasticity at Each Point [22] 
Based on the AASHTO Classification System, all samples are below the A-line and to the right of 50\% LL so that the 5 (five) samples are categorized as inorganic silt with high plasticity or MH.

Laboratory testing to assess the free swell index was also carried out on 5 (five) samples. The classification of development potential was carried out using Holtz and Gibbs [23] and is shown in Table 4, which is why the results of the free swell examination can be classified as in Table 5:

Table 4. Free Swell Classification according to Holtz and Gibbs

\begin{tabular}{|c|c|}
\hline Free Swell Index $(\%)$ & Classification \\
\hline$<20$ & Low \\
\hline $20-35$ & Medium \\
\hline $35-50$ & High \\
\hline$>50$ & Very High \\
\hline
\end{tabular}

Table 5. Free Swelling Test Results

\begin{tabular}{|c|c|c|c|l|}
\hline Sample & $\begin{array}{c}\text { Initial Height } \\
(\mathrm{ml})\end{array}$ & $\begin{array}{c}\text { Final Height } \\
(\mathrm{ml})\end{array}$ & $\begin{array}{c}\text { FS } \\
(\%)\end{array}$ & Classification \\
\hline L 1 & 20 & 35 & 75 & Very High \\
\hline L 2 & 20 & 43 & 115 & Very High \\
\hline L 3 & 20 & 42 & 110 & Very High \\
\hline L 4 & 20 & 39 & 95 & Very High \\
\hline L 5 & 20 & 36 & 80 & Very High \\
\hline
\end{tabular}

From 5 (five) samples tested, all samples were classified as samples having very high Free Swell values according to Holtz and Gibbs [23]. Slake Durability Testing was also carried out on 5 (five) samples to determine the Slake Durability Index (SDI). Slake Durability Testing qs performed using 2 (two) cycles. To find out the durability classification, first cycle SDI and second cycle SDI values can be obtained using Table 6 [24]. For the results of slake durability testing on the 5 (five) samples can be seen in Table 7 .

Table 6. Gamble's Slake Durability Classification

\begin{tabular}{|c|c|c|}
\hline Group Name & $\begin{array}{c}\text { \% retained after } \\
\text { first 10 min cycle } \\
\text { (dry weight } \\
\text { basis) }\end{array}$ & $\begin{array}{c}\text { \% retained after } \\
\text { second 10 min } \\
\text { cycle (dry weight } \\
\text { basis) }\end{array}$ \\
\hline Very High Durability & $>99$ & $>98$ \\
\hline High Durability & $98-99$ & $95-98$ \\
\hline Medium High Durability & $95-98$ & $85-95$ \\
\hline Medium Durability & $85-95$ & $60-85$ \\
\hline Low Durability & $60-85$ & $30-60$ \\
\hline Very Low Durability & $<60$ & $<30$ \\
\hline
\end{tabular}

Based on Gamble's Slake Durability Classification in Table 5, the analysis results of Slake Durability testing in Table 6 can be classified as Very Low Durability. These results indicate that clay shale has a very low durability and is easily weathered when experiencing changes in wet and dry conditions.

In the UCS test, there are several parameters tested, namely free compressive strength, maximum strain, and elastic modulus for several drying treatments. Free compressive strength is the compressive strength in samples with a diameter of $50 \mathrm{~mm}$ and a height of 100 $\mathrm{mm}$. Maximum strain is the maximum strain at maximum stress. The calculated modulus of elasticity is E50 and Etan. For the results of stress strain relationships with variations in the length of drying in the UCS test can be seen in Table 8 and Figure 4, Figure 5, and Figure 6. Statistical data can be noticed on the table 9. While for the percentage decrease in the value of UCS, E50 and Etan can be noticed on the Table 10 .

Table 7. Slake Durability Test Results

\begin{tabular}{|c|c|c|c|c|c|c|c|}
\hline \multirow{2}{*}{ Sample } & $\begin{array}{c}\text { Initial Wet } \\
\text { Weight }\end{array}$ & $\begin{array}{c}\text { Initial } \\
\text { Dry } \\
\text { Weight }\end{array}$ & $\begin{array}{c}\text { Retained } \\
\text { Weight First } \\
\text { Cycle }\end{array}$ & $\begin{array}{c}\text { Retained Weight } \\
\text { Second Cycle }\end{array}$ & $\begin{array}{c}\text { SDI First } \\
\text { Cycle }\end{array}$ & $\begin{array}{c}\text { SDI } \\
\text { Second } \\
\text { Cycle }\end{array}$ & Durability Classification \\
\cline { 2 - 6 } & (gram) & (gram) & (gram) & (gram) & $(\%)$ & $(\%)$ & \\
\hline L 1 & 541.33 & 449.82 & 8.38 & 2.83 & 1.86 & 0.41 & V. Low Durability \\
\hline L 2 & 567.84 & 472.80 & 10.98 & 1.05 & 2.32 & 0.49 & V. Low Durability \\
\hline L 3 & 696.34 & 582.99 & 28.03 & 0.67 & 4.81 & 0.82 & V. Low Durability \\
\hline L 4 & 477.55 & 373.25 & 27.31 & 1.11 & 7.32 & 1.96 & V. Low Durability \\
\hline L 5 & 513.04 & 403.92 & 107.74 & 3.49 & 26.67 & 6.60 & V. Low Durability \\
\hline
\end{tabular}


The Effect of Clay Shale Drying on the Reduction of Compressive Strength and Durability in Bawen Sub-District, Semarang Regency

Table 8. Results of UCS, $\mathrm{E}_{50}$, and Ethane

\begin{tabular}{|c|c|c|c|c|c|c|c|c|c|c|c|c|}
\hline \multirow{3}{*}{ Location } & \multicolumn{3}{|c|}{0 minute } & \multicolumn{3}{|c|}{30 minutes } & \multicolumn{3}{|c|}{60 minutes } & \multicolumn{3}{|c|}{90 minutes } \\
\hline & $\mathrm{q}_{\mathrm{u}}$ & $\mathrm{E}_{50}$ & $\mathrm{E}_{\text {tan }}$ & $\mathrm{q}_{\mathrm{u}}$ & $\mathrm{E}_{50}$ & $\mathrm{E}_{\mathrm{tan}}$ & $\mathrm{q}_{\mathrm{u}}$ & $\mathrm{E}_{50}$ & $\mathrm{E}_{\mathrm{tan}}$ & $\mathrm{q}_{\mathrm{u}}$ & $\mathrm{E}_{50}$ & $\mathrm{E}_{\text {tan }}$ \\
\hline & \multicolumn{3}{|c|}{$\left(\mathrm{kN} / \mathrm{m}^{2}\right)$} & \multicolumn{3}{|c|}{$\left(\mathrm{kN} / \mathrm{m}^{2}\right)$} & \multicolumn{3}{|c|}{$\left(\mathrm{kN} / \mathrm{m}^{2}\right)$} & \multicolumn{3}{|c|}{$\left(\mathrm{kN} / \mathrm{m}^{2}\right)$} \\
\hline 1 & 2675.31 & 1671.56 & 1875.55 & 1868.99 & 1604.90 & 1752.41 & 1308.28 & 1245.98 & 1669.52 & 488.69 & 952.69 & 852.52 \\
\hline 2 & 2606.19 & 1551.30 & 1761.88 & 2100.69 & 1479.36 & 1740.57 & 1772.79 & 1284.63 & 1669.52 & 1390.25 & 1219.52 & 1385.35 \\
\hline 3 & 3125.35 & 1936.40 & 2259.19 & 2237.31 & 1381.05 & 1733.46 & 1991.39 & 1363.96 & 1562.96 & 1472.22 & 980.18 & 1522.36 \\
\hline 4 & 3070.70 & 1754.69 & 2188.14 & 2565.20 & 1401.75 & 1932.39 & 1458.56 & 1144.87 & 1657.68 & 1280.95 & 1133.59 & 1515.60 \\
\hline 5 & 2852.11 & 1906.49 & 2083.95 & 2291.96 & 1810.39 & 2060.26 & 1950.40 & 1493.42 & 1847.13 & 1239.97 & 1278.31 & 1705.05 \\
\hline
\end{tabular}

Table 9. Data Statistik Hasil UCS, $\mathrm{E}_{50}$, and Ethane

\begin{tabular}{|c|c|c|c|c|c|c|c|c|c|c|c|c|}
\hline \multirow{3}{*}{ Location } & \multicolumn{3}{|c|}{0 minute } & \multicolumn{3}{|c|}{30 minutes } & \multicolumn{3}{|c|}{60 minutes } & \multicolumn{3}{|c|}{90 minutes } \\
\hline & $\mathrm{q}_{\mathrm{u}}$ & $E_{50}$ & $\mathrm{E}_{\text {tan }}$ & $\mathrm{q}_{\mathrm{u}}$ & $\mathrm{E}_{50}$ & $\mathrm{E}_{\text {tan }}$ & $\mathrm{q}_{\mathrm{u}}$ & $\mathrm{E}_{50}$ & $\mathrm{E}_{\text {tan }}$ & $\mathrm{q}_{\mathrm{u}}$ & $E_{50}$ & $\mathrm{E}_{\text {tan }}$ \\
\hline & \multicolumn{3}{|c|}{$\left(\mathrm{kN} / \mathrm{m}^{2}\right)$} & \multicolumn{3}{|c|}{$\left(\mathrm{kN} / \mathrm{m}^{2}\right)$} & \multicolumn{3}{|c|}{$\left(\mathrm{kN} / \mathrm{m}^{2}\right)$} & \multicolumn{3}{|c|}{$\left(\mathrm{kN} / \mathrm{m}^{2}\right)$} \\
\hline 1 & 2865.93 & 1764.09 & 2033.74 & 2212.83 & 1535.49 & 1843.82 & 1696.28 & 1306.57 & 1681.36 & 1174.42 & 1112.86 & 1396.18 \\
\hline 2 & 3125.35 & 1936.40 & 2259.19 & 2565.20 & 1810.39 & 2060.26 & 1991.39 & 1493.42 & 1847.13 & 1472.22 & 1278.31 & 1705.05 \\
\hline 3 & 2606.19 & 1551.30 & 1761.88 & 1868.99 & 1381.05 & 1733.46 & 1308.28 & 1144.87 & 1562.96 & 488.69 & 952.69 & 852.52 \\
\hline 4 & 230.88 & 161.17 & 209.83 & 255.85 & 176.97 & 146.53 & 301.90 & 130.87 & 102.88 & 394.06 & 143.56 & 324.53 \\
\hline 5 & 2865.93 & 1764.09 & 2033.74 & 2212.83 & 1535.49 & 1843.82 & 1696.28 & 1306.57 & 1681.36 & 1174.42 & 1112.86 & 1396.18 \\
\hline
\end{tabular}


Table 10. Percentage of Impairment of UCS, $E_{50}$ and $E_{\tan }$

\begin{tabular}{|c|c|c|c|c|c|c|c|c|c|}
\hline \multirow{3}{*}{ Location } & \multicolumn{3}{|c|}{$\mathrm{q}_{\mathrm{u}}$} & \multicolumn{3}{|c|}{$\mathrm{E}_{50}$} & \multicolumn{3}{|c|}{$\mathrm{E}_{\tan }$} \\
\hline & \multicolumn{3}{|c|}{ Drying Time } & \multicolumn{3}{|c|}{ Drying Time } & \multicolumn{3}{|c|}{ Drying Time } \\
\hline & $\begin{array}{c}0-30 \\
\text { (minutes) }\end{array}$ & $\begin{array}{c}0-60 \\
\text { (minutes) }\end{array}$ & $\begin{array}{c}0-90 \\
\text { (minutes) }\end{array}$ & $\begin{array}{c}0-30 \\
\text { (minutes) }\end{array}$ & $\begin{array}{c}0-60 \\
\text { (minutes) }\end{array}$ & $\begin{array}{c}0-90 \\
\text { (minutes) }\end{array}$ & $\begin{array}{c}0-30 \\
\text { (minutes) }\end{array}$ & $\begin{array}{c}0-60 \\
\text { (minutes) }\end{array}$ & $\begin{array}{c}0-90 \\
\text { (minutes) }\end{array}$ \\
\hline 1 & $30 \%$ & $51 \%$ & $82 \%$ & $4 \%$ & $25 \%$ & $43 \%$ & $7 \%$ & $11 \%$ & $55 \%$ \\
\hline 2 & $19 \%$ & $32 \%$ & $47 \%$ & $5 \%$ & $17 \%$ & $21 \%$ & $1 \%$ & $5 \%$ & $21 \%$ \\
\hline 3 & $28 \%$ & $36 \%$ & $53 \%$ & $29 \%$ & $30 \%$ & $49 \%$ & $23 \%$ & $31 \%$ & $33 \%$ \\
\hline 4 & $16 \%$ & $53 \%$ & $58 \%$ & $20 \%$ & $35 \%$ & $35 \%$ & $12 \%$ & $24 \%$ & $31 \%$ \\
\hline 5 & $20 \%$ & $32 \%$ & $57 \%$ & $5 \%$ & $22 \%$ & $33 \%$ & $1 \%$ & $11 \%$ & $18 \%$ \\
\hline Average & $23 \%$ & $41 \%$ & $59 \%$ & $12 \%$ & $26 \%$ & $36 \%$ & $9 \%$ & $17 \%$ & $31 \%$ \\
\hline $\begin{array}{c}\text { Total } \\
\text { Average }\end{array}$ & \multicolumn{3}{|c|}{$41 \%$} & \multicolumn{3}{|c|}{$25 \%$} & \multicolumn{3}{|c|}{$19 \%$} \\
\hline
\end{tabular}

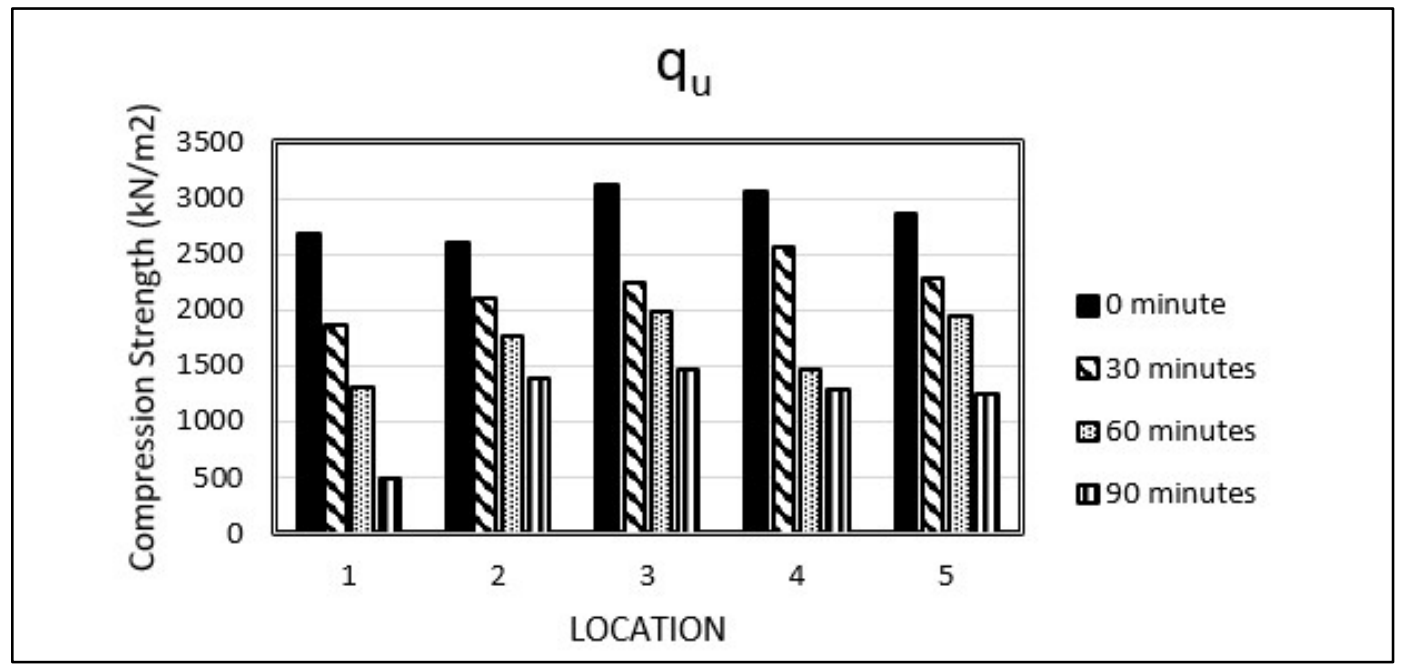

Figure 4. Unconfined Compression Strength (UCS) Graph

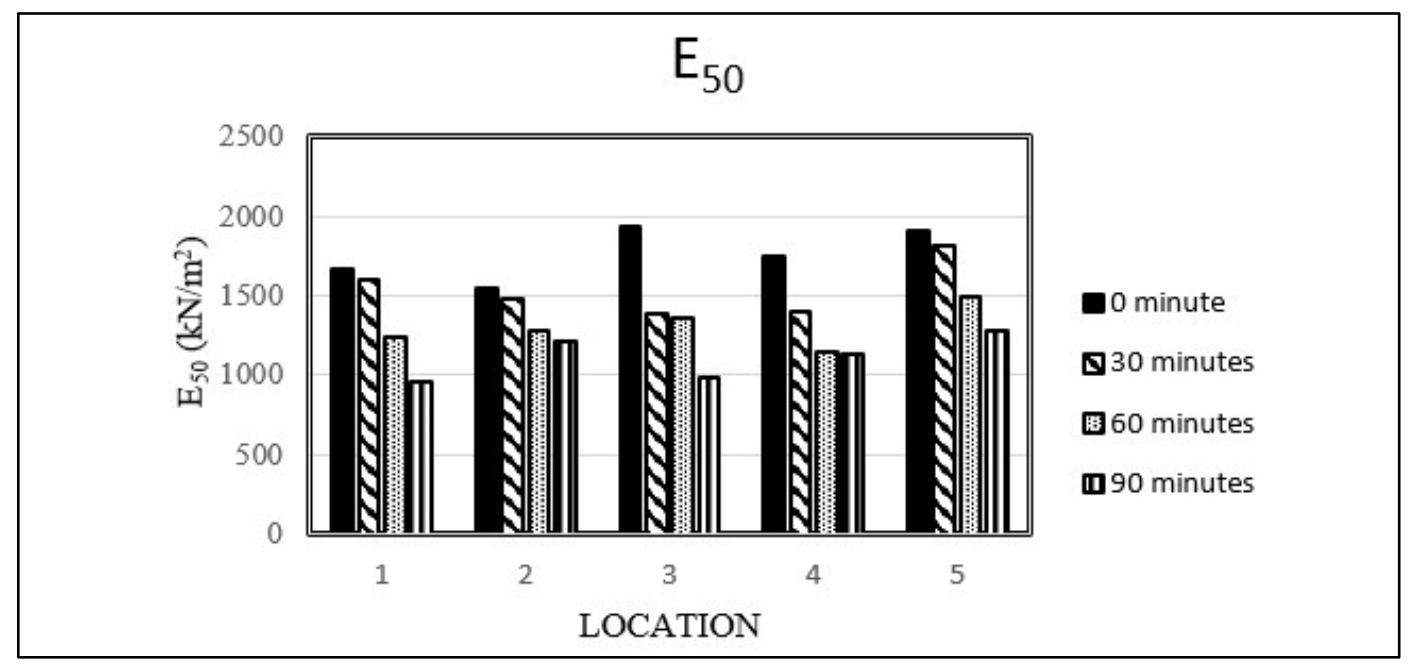

Figure 5. $\mathrm{E}_{50}$ Modulus of Elasticity Graph 


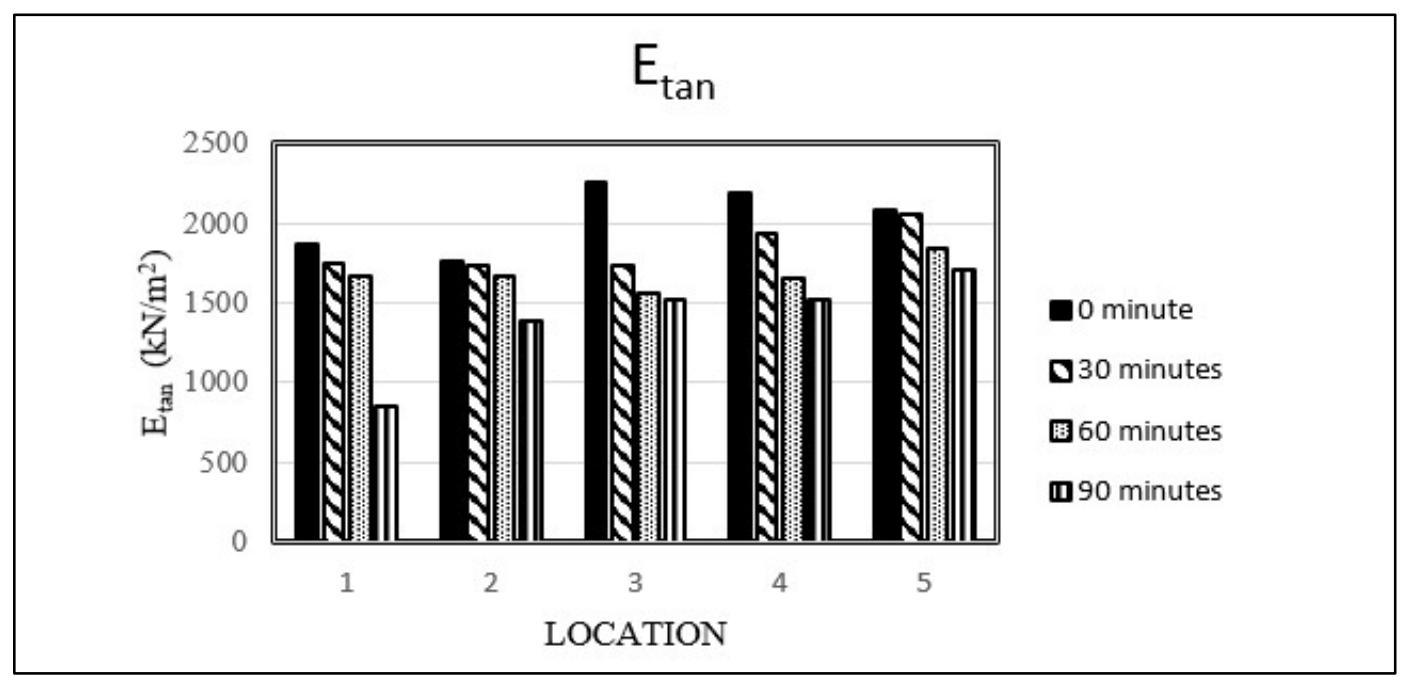

Figure 6. Modulus Graph of $\mathrm{E}_{\mathrm{tan}}$ Elasticity

From all the UCS test samples, it can be said that the percentage decrease in Qu value at 30 minutes of drying is $23 \%$, 60 minutes of drying is $41 \%$, and 90 minutes of drying is $59 \%$. This can be attributed to research conducted [9], that the compressive strength $(\mathrm{Qu})$ of clay shale decreased by $55.02 \%$ during the first cycle of the drying wetting process. After going through the second cycle, the $\mathrm{Qu}$ value has decreased by $70.41 \%$. The decrease in $\mathrm{Qu}$ value after going through the 90 minutes drying process is $59 \%$, which is almost the same as the decrease in $\mathrm{Qu}$ value after going through $1 \mathrm{x}$ the wetting and drying cycle of $55.02 \%$ conducted [9].

The percentage decrease in E50 at 30 minutes of drying is $12 \%, 60$ minutes of drying is $26 \%$, and 90 minutes of drying is $36 \%$. The percentage decrease in Etan value for 30 minutes of drying is $9 \%, 60$ minutes of drying is $17 \%$, and 90 minutes of drying is $31 \%$. The result of this decrease percentage is obtained in 1 (one) drying cycle while in a study conducted by Ariesnawan (2015), the clay shale modulus of elasticity also experienced changes due to the wetting and drying cycle. Modulus of elasticity in cycle 1 (one) decreased by $56.36 \%$, while in cycle 2 (two) it decreased by $60.14 \%$. The decrease in the modulus of elasticity (E50 and Etan) after going through the 90 minutes drying process is $36 \%$ for E50 and 31\% for Etan, where this result has a value of approximately $50 \%$ of the $2 \mathrm{x}$ cycle of modulus of elasticity reduction in the research conducted by Ariesnawan (2015), i.e. 60.14\%.

In the research [9], what is meant by $1 \mathrm{x}$ the wetting and drying cycle is the process of the wetting and drying cycle carried out by reducing the water content from initial conditions to $100 \%$ dry conditions then adding water to $100 \%$ saturated water conditions. The addition of water is given in stages by $20 \%$ of the saturated water content.

\section{Correlation between Results and Clay Shale Properties}

From the value of Compression strength and the value of loss water content correlation graph relationship can be made between the two. The relationship can be seen in Figure 7, Figure 8, Figure 9, Figure 10, and Figure 11 as follows: 


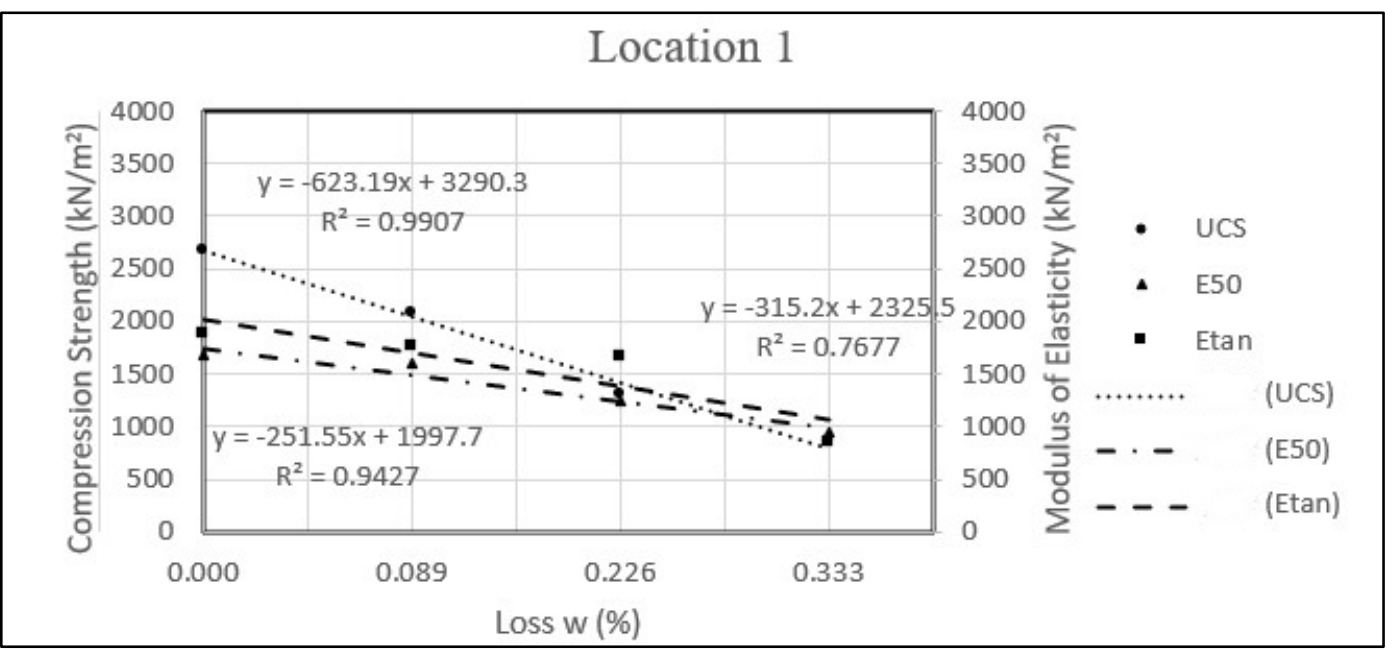

Figure 7. Correlation between UCS and Modulus of Elasticity with Loss Water Content at Location 1

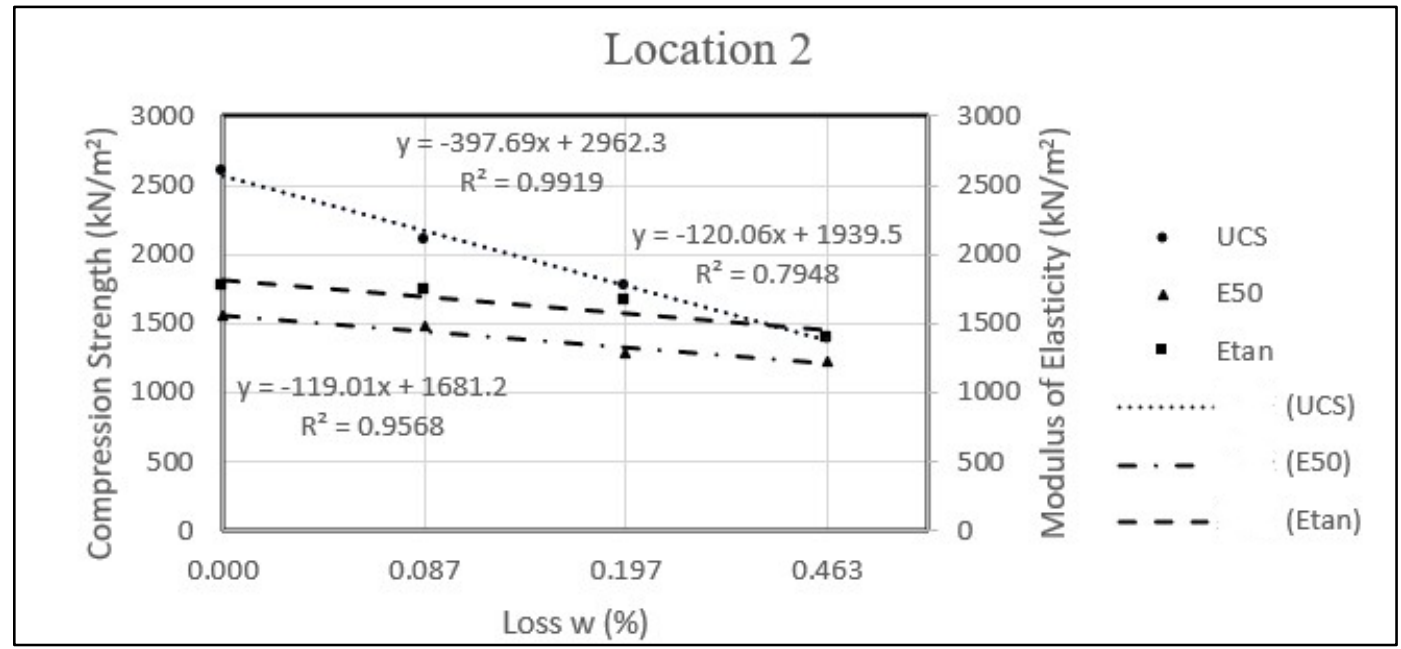

Figure 8. Correlation of UCS and Modulus of Elasticity with Loss Water Content at Location 2

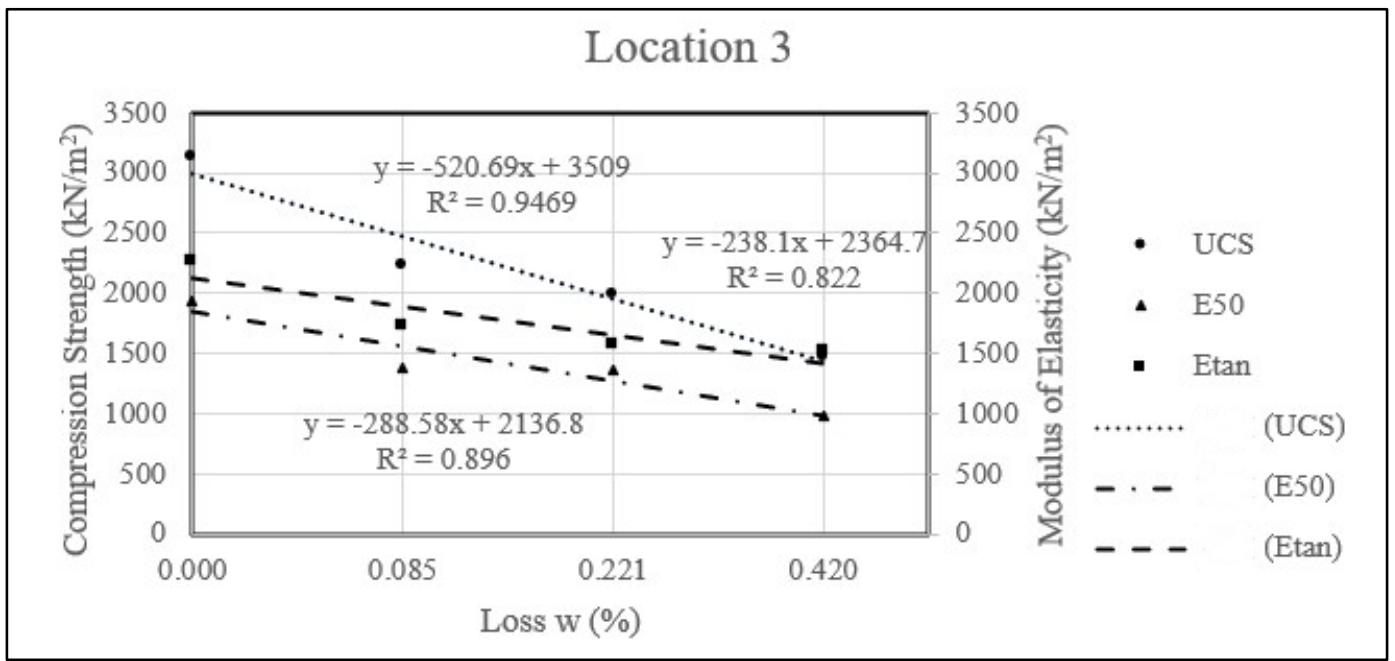

Figure 9. Correlation between UCS and Modulus of Elasticity with Loss Water Content at Location 3 


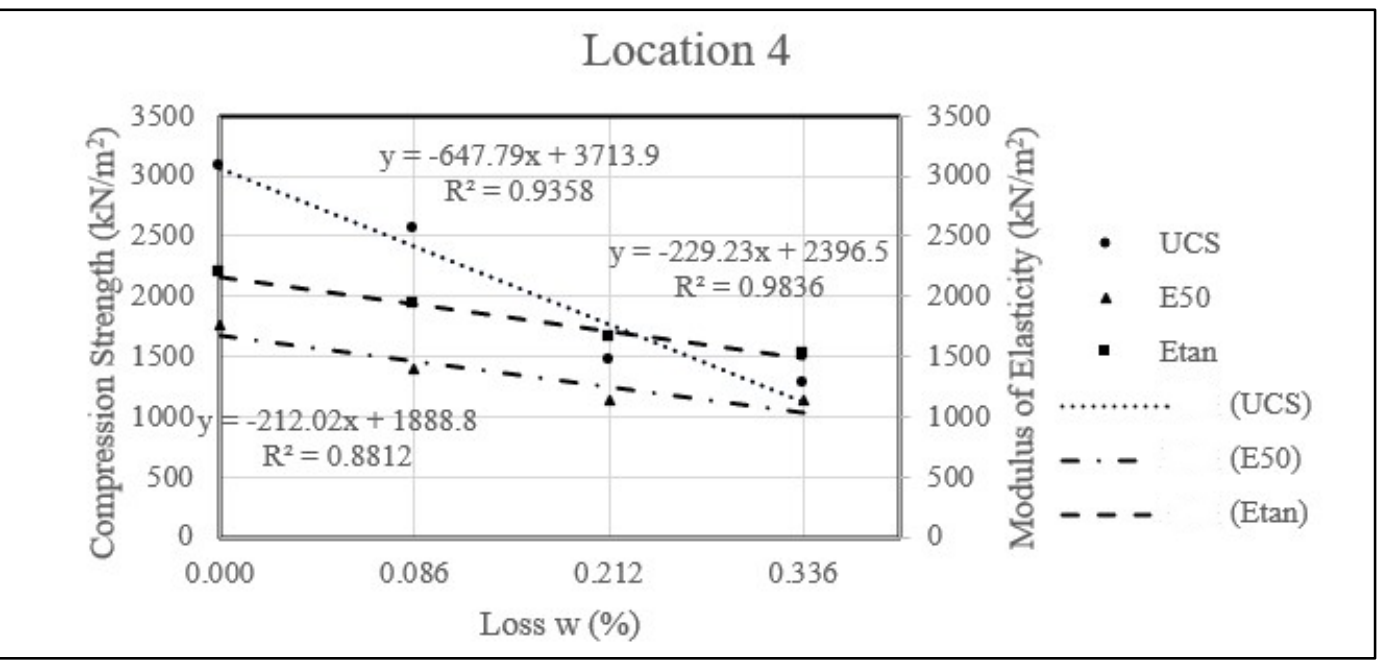

Figure 10. Correlation of UCS and Modulus of Elasticity with Loss Water Content at Location 4

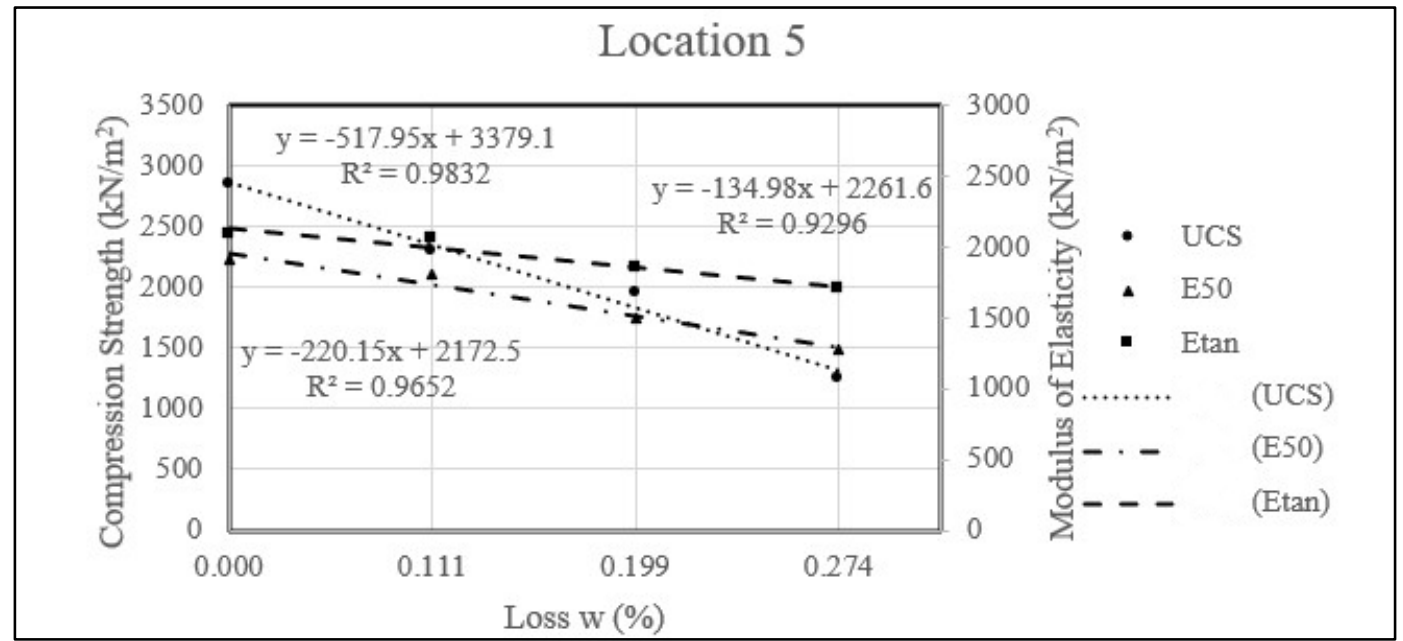

Figure 11. Correlation of UCS and Modulus of Elasticity with Loss Water Content at Location 5

From the five graphs above, it is known that the tendency of the value of the loss water content is getting bigger causing the UCS, $\mathrm{E}_{50}$, and $\mathrm{E}_{\tan }$ values to be getting smaller. The approach formula for the correlation of UCS, $\mathrm{E}_{50}$, and $\mathrm{E}_{\tan }$ values with water content values can be seen on each graph.

\section{Conclusion}

Based on the mechanical properties of clay shale in submerged conditions and the effect of drying, it can reduce the value of UCS, E50 and Etan. The rock properties from the Slake Durability test, it is discovered that clay shale is very easy to weathering since all clay shale samples have very low durability properties.

The reduction in $\mathrm{Qu}$ value after going through the 90 minutes drying process is $59 \%$, which its reduction is almost the same as the reduction in Qu value after going through ones wetting and drying cycle of $55.02 \%$ conducted [9]. While the reduction in the modulus of elasticity (E50 and Etan) after going through 90 minutes drying process is $36 \%$ for E50 and $31 \%$ for Etan, which means that this result has a value of approximately $50 \%$ of the twice cycle of modulus of elasticity decline in research conducted by [9] that is $60.14 \%$.

The correlation between the value of UCS and Modulus of Elasticity (E50 and Etan) with the value of Loss Water Content have a declining trend, which means the greater the value of loss water content, the smaller the value of UCS and Modulus of Elasticity.

\section{REFERENCES}

[1] Terzaghi K., "Measurement of Stresses in Rock," Journal of Geotechnique, vol. 12, no.2, pp. 105 - 124, 1962. DOI: 10.1680/geot.1962.12.2.105

[2] J. A. Franklin, R. Chandra, "The Slake-Durability Test," Journal of Rock Mechanics and Mining Sciences and Geomechanics, vol. 9 , no. 3 , pp. $325-328$, 1972. DOI: 


\section{$10.1016 / 0148-9062(72) 90001-0$}

[3] L. R. Bates, J. A. Jackson, in Dictionary of Geological Terms, 3rd ed, DoubleDay, 1984.

[4] Budijanto Widjaja, "Analisis Batas Untuk Kestabilan Lereng," Jurnal Teknik Sipil, vol. 1, no. 1, pp. 19-28, 2004. ISBN: 1411-5360.

[5] I. M. Alatas, S. A. Kamaruddin, R. Nazir, M. Irsyam, A. Himawan,. "Shear Strength Degradation of Semarang Bawen Clay Shale Due to Weathering Process," Jurnal Teknologi, vol. 77, no. 11, pp. $109-118,2015$. ISBN: 2180-372.

[6] I. M. Alatas, P. T. Simatupang, "Pengaruh Proses Pelapukan Clay Shale Terhadap Perubahan Parameter Rasio Disintegritas $\left(\mathrm{D}_{\mathrm{R}}\right)$," Journal of Civil Engeneering ITB, vol. 24, no. 1, pp. $77-82,2017$. ISBN: 0853-2982.

[7] A. Pratiwi, "Back Analysis of Clay Shale Landslide on Penggaron Bridge," in Magister Teknik Tesis, Parahyangan University, 2017.

[8] R. A. Ariesnawan, "Karakteristik Mekanik Dan Dinamik Clay Shale Kabupaten Tuban Terhadap Perubahan Kadar Air" in Magister Teknik Tesis, Institut Teknologi Sepuluh November, 2015.

[9] M. Ghafoori, M. Mastropasqua, J. P. Caster, D. W. Airey, "Engineering Properties of Ashfield Shale, Australia," Bulletin of the International Association of Engineering Geology, vol. 1, no. 48, pp. 43 - 58, 1993. DOI: 10.1007/BF02594975.

[10] C. Gökceoglu, R. Ulusay, H. Sönmez, "Factors Affecting the Durability of Selected Weak and Clay-Bearing Rocks from Turkey, with Particular Emphasis on the Influence of the Number of Drying and Wetting Cycles," Journal of Engineering Geology, vol. 57, no. 3, pp. 215 - 237, 2000. DOI: $10.1016 / \mathrm{S} 0013-7952(00) 00031-4$.

[11] W. C. Haneberg, S. A. Anderson, in Clay and Shale Slope Instability, 4th ed, The Geological Society of America, 1995.

[12] E. A. G. Marques, E. D. A. Vargas, F. S. Antunes, “A Study of the Durability of Some Shales, Mudrocks and Siltstones from Brazil," Journal of Geotechnical and Geological Engineering, vol. 23, no. 3, 321 - 348, 2005. DOI: 10.1007/s10706-004-1605-5.

[13] Dinas Energi dan Sumberdaya Mineral. "Peta Zona Kerentanan Gerakan Tanah Kabupaten Semarang, Jawa Tengah. Jawa Tengah", ESDM, https://esdm.jatengprov.go. $\mathrm{id} /$. (accessed Jan. 2, 2008)

[14] R. E. Thanden, Pusat Survei Geologi, in Geological map of the Magelang and Semarang sheets, 1st ed, Jawa, Pusat Survei Geologi, 2006.

[15] Annual Book of ASTM Standars, "Test Method" in ASTM C-29/C29M-09 Standard Test Method For Bulk Density, 1st ed, AASHTO, 2009.

[16] Annual Book of ASTM Standars, "Test Method" in ASTM D 2216 Standard Test Methods for Laboratory Determination of Water (Moisture) Content of Soil and Rock by Mass, 1st ed, AASHTO, 2010.

[17] Annual Book of ASTM Standars, "Test Method" in ASTM International D 854 Standard Test Methods for Specific Gravity of Soil Solids by Water Pycnometer, 1st ed, AASHTO, 2010.

[18] Annual Book of ASTM Standars, "Test Method" in ASTM International D 4318 Standard Test Methods for Liquid Limit, Plastic Limit, and Plasticity Index of Soils, 1st ed, AASHTO, 2010.

[19] Annual Book of ASTM Standars, "Test Method" in ASTM International D 720 Standard Test Method for Free-Swelling Index of Coal, 1st ed, AASHTO, 2015.

[20] Annual Book of ASTM Standars, "Test Method" in ASTM International D 4644 Standard Test Method for Slake Durability of Shales and Other Similar Weak Rocks, 1st ed, AASHTO, 2016.

[21] Annual Book of ASTM Standars, "Test Method" in ASTM International D 2166 Standard Test Method for Unconfined Compressive Strength of Cohesive Soil, 1st ed, AASHTO, 2016.

[22] B. M. Das, K. Sobhan, "Classification of Soil" in Principles of Geotechnical Engineering, 9th ed, Cengage Learning, 2016.

[23] W. G. Holtz, H. J. Gibbs, "Triaxial Shear Tests on Pervious Gravelly Soils," Journal of the Soil Mechanics and Foundations Division, vol. 82, no. 1, pp. 1-22, 1956.

[24] R. E. Goodman, "Classification and Index Properties of Rocks" in Introduction to Rock Mechanics, 2nd ed, John wiley and sons, 1989.

[25] R. E. Thanden, H. Sumadirdja, P. W. Richards, K. Sutisna, T. C. Amin, "Geological Map of The Magelang and Semarang Sheets, Jawa", 1996.

[26] Gamil, Y., Zamahri, K. A., \& Bakar, I. (2018). Application of Scheffe's Theory to Develop Mathematical Prediction Model to Predict UCS for Hybrid Containing Organic Soil and POFA-OPC Additives. Civil Engineering and Architect ure, 6(2), 54-64. 